\title{
Contributions of Arm Muscle Strength Against Forehand Drive Skills for Table Tennis Athletes
}

\author{
*Dessi Novita Sari, Indri Wulandari, \\ Sefri Hardiansyah, Zulbahri \\ Sport Education Program \\ Faculty of Sport Education and Health \\ Padang State University \\ Padang, Indonesia \\ * dessinovita10@fik.unp.ac.id, \\ indriwulandari@fik.unp.ac.id, \\ hardiansyah@fik.unp.ac.id, \\ zulbahri@fik.unp.ac.id
}

\begin{abstract}
This study aims to determine the contribution of the arm muscle strength against forehand drive skill for Semen Padang table tennis athletes. This type of research is correlational made to the table tennis athletes Semen Padang. Arm muscle strength measured using the dynamometer was expanding tools, and skills with a forehand drive targets on the table. The result showed that: there is a contribution to the arm muscle strength skills of table tennis athletes forehand drive Semen Padang. The research proves that their Contributions significantly between the arm muscle strength against forehand drive with acquired skills $\mathbf{r}_{\text {observe }} \mathbf{0 . 6 4}$ and $\mathbf{r}_{\text {table }}$ in early stages $\square$ $=0.05$ at .553 with a contribution of $40.96 \%$.
\end{abstract}

Keywords-Arm muscle strength, table tennis skill, forehand drive

\section{INTRODUCTION}

"Sports are sports that foster achievement and develop a planned sportsman, tiered, and continuing through the competition to achieve with the support of sports science and technology" [1].

From the quote above, it is explained that the formation and development of the sport should be developed as early as possible, to create generations of young achievers and the name of the nation. Achievement which was obtained from a program that is planned, in stages, and sustained and supported by science and technology sport. One of them on the sport of table tennis.

Table tennis is a sport that has the unique movements and dynamic involving all limbs. Factors affecting the form of table tennis physical conditions such as: strength, agility, speed, endurance, flexibility, and coordination of movement. In addition to the physical condition, aspects that play an important role in that table tennis grip, stance, stroke (stroke), and footwork.

Many stroke technique in the sport of table tennis, among others: push, block, chop, servicing, flat, counter hitting, topspin, drop shot, smash chopped, looped drive, drive, and flick [2]. One blow to frequent attacks carried out in the table tennis tournament is forehand drive. To be able to hit a forehand drive perfectly, one must have a good arm muscle strength.

Problems encountered as the low skills of table tennis forehand drive. This is due to several factors such as the arm muscle strength, hand grip strength, hand-eye coordination in doing blow, perkenaan ball with a bat used, the timing when hitting the ball.

Of these problems, the authors are interested in doing a study on the contribution of physical condition and skills forehand drive is "Contributions Strength of arm muscle against Athletes Skills Table Tennis Forehand drive Semen Padang".

Table Tennis

"Table tennis is the most famous sport in the world and the number of participants in second place. In another sense table tennis is a game where a little white ball being hit back and forth until someone made a mistake "[3].

"Table tennis can be played by individuals or groups. Games with individuals that played a game or singular, whereas the group that is a game played with a double and teams. Doubles is played by two people, both women with women, men with men, and women with men who are called to the mixed doubles. For one team in the game in table tennis team consists of four people and should not be more "[4].

From the above opinion, the authors conclude that table tennis is a sport that can be played by individuals or groups, using equipment table, ball, net and bet. Which begins with a service should be able to get across and return the ball over the net to the opponent and ends by mistake or death game opponent. With the idea of tossing a ball game as long as possible or as soon as possible turn off the game opponents.

The basic technique in a game of table tennis can be distinguished: grip (grip), stance (ready position), stroke (stroke) and footwork (footsteps) [2].

stroke

"We learn techniques for doing stroke, learn to control all movement of the body and the ball itself, learn to move your body and hit the ball correctly and consistently "[4]. 
"There are several techniques blow in a game of table tennis, among others: push, block, chop, service, flat, counter hitting, topspin, drop shot, smash chopped, looped drive, drive, flick" [2].

So the authors conclude stroke are the kinds of blows in the game of table tennis and do the techniques in controlling all movement of the body and the ball itself. And learn to move the body and hit the ball correctly and consistently.

\section{Skills Forehand Drive}

"drive is the smallest blow spin. Punch drive, which is often called the elevator, is the basis of various types of punch attack. Therefore, the punch drive also referred to as the parent of a punch attack techniques. Punch drive a flat punch which have some differences in terms of shape. Drive is one of the important stroke technique fatherly face defensive game "[5]. Forehand is performed with every shot bet that moved to the right elbow for players who use the right hand, and left for players who use the left hand. Backhand is a blow that is done by moving the bet to the left elbow for players who use the right hand, and the opposite for players who use the left hand "[3].

Based on the above quote can be concluded forehand drive to position the left foot in front, right foot in the rear (for right-handed players, being left handed player instead). Agency $\pm 45^{\circ}$ diagonally to the right knee is bent. Bet pulled to the rear side toward the right elbow for a right-handed player and to the left of the player who uses his left hand. Head bet facing oblique to the ground with arms slightly downward. The wrist is not bent.

Mistakes made in forehand drive such as: hitting the ball too close or a meeting with the body, hit the ball too far away from the body (the ball too in front of or in addition to), not strong enough hold the bat when contact with the ball, not waiting for the ball to bounce high enough , swinging his hands up before swinging forward.

\section{Arm Muscle Strength}

"Some forms of strength training is usually done for table tennis athletes include: crunches, straddle hops, the extension of the body, bench press, lateral raise (lie), curl your arms and wrists, triceps stretch, wrist extension, supination and pronation ankle hand, rowing, high pull, turn the body, pull over, and snactch "[2].

Quote the opinion of experts explaining one aspect of the physical conditions are very influential in table tennis that is strength. Strength is the basis of a person in order to make a good activity. The formation of the power not only take energy from food intake, but also takes the form of exercise treatment in accordance with the needs and goals to be achieved.

"Factors that influence the strength, among others: coordination intermuscular, intramuscular coordination, muscle reactions to nerve stimulation, and corner joints" [6].

From opinions above explains the arm muscle strength is the ability to hold the arm muscles or accept the burden in carrying out the activity properly.

Physical condition are discussed in this study is the strength in the arm muscles, which conduct tests of muscle strength by using the tool Expanding encourage dynamometer. If an athlete's arm muscle strength table tennis and stronger it will support the creation of the skills a good forehand drive. Thus, in this study will look at the contribution of the arm muscle strength against skill forehand drive.

\section{RESEARCH METHODOLOGY}

This study is a correlational study. This study aims to detect the extent of variations in one or more other factors based on the correlation coefficient [7]. In other words, this study will look Contributions between one variable to another variable. Place of research done in the field of table tennis, GOR Semen Padang, Member of the samples selected specifically based on objective research that senior athletes only son. Then the sampling technique used was purposive sampling. The technique used in this research is the analysis of product moment correlation and multiple correlation, hypothesis testing previously done with the test requirements analysis, test data normality test Liliefors [8]

$$
r_{x y}=\frac{\mathrm{n} \sum \mathrm{xy}-\left(\sum \mathrm{x}\right)\left(\sum \mathrm{y}\right)}{\sqrt{\left\{\mathrm{n} \sum \mathrm{x}^{2}-\left(\sum \mathrm{x}\right)^{2}\right\}\left(\mathrm{n} \sum \mathrm{y}^{2}-\left(\sum \mathrm{y}\right)^{2}\right\}}}
$$

\section{RESULTS}

\section{Arm Muscle Strength}

Data

Based on the arm muscle strength tests of some samples were obtained the highest score was 37 and the lowest score was 16 . Besides, the obtained value mean $=25.53$, mode $=$ 16 , median $=25$, standard deviation $=6.89$ and range $=21$. For more details variable group frequency distribution arm muscle strength can be seen in the table below:

Table 1. Frequency Distribution Arm Muscle Strength

\begin{tabular}{ccc}
\hline class interval & $\begin{array}{l}\text { frequency } \\
\text { Absolut }\end{array}$ & $\begin{array}{l}\text { Relative } \\
\text { Frequency (\%) }\end{array}$ \\
\hline $16-20$ & 3 & 20 \\
\hline $21-25$ & 5 & 33.33 \\
\hline $26-30$ & 3 & 20 \\
\hline $31-35$ & 3 & 20 \\
\hline $36-40$ & 1 & 6.667 \\
\hline Amount & 15 & 100 \\
\hline
\end{tabular}

In table 1 above of 15 samples, 3 (20\%) have the arm muscle strength ranging between 16-20, 5 (33.33\%) had forearm muscle strength ranging between 21-25, 3 (20\%) arm muscle strength ranging between 26-30, 3 (20\%) have the arm muscle strength ranging between $31-35,1$ (6.67\%) had the arm muscle strength ranging between 36-40. From the above description can be explained from the 15 samples, that scored above average there are 4 people $(26.67 \%)$, which has a score in the average group there were 3 people (20\%), and those with scores below the average 8 people $(53.33 \%)$.

Based on the above concluded that the strength of the arm muscles owned Semen Padang Table Tennis Athletes not in accordance with the desired expectation, with these can affect athletes in scholastic achievement. For more 
details can be seen on the histogram frequency distribution arm muscle strength below:

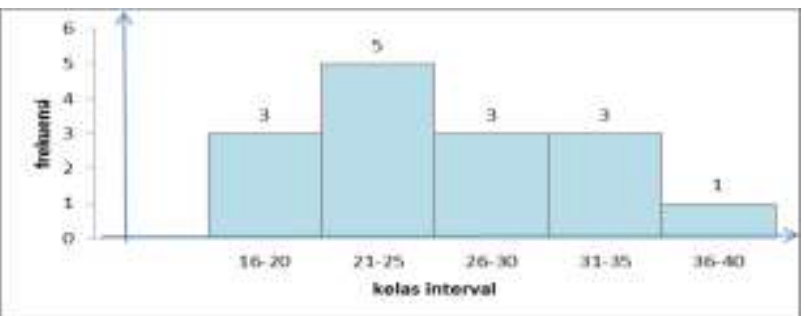

Figure 1.Histogram Frequency Distribution Arm Muscle Strength

\section{Skills Forehand Drive}

Based on the results of a test of skill forehand drives, the result for the maximum score $=26$ and a minimum score $=$ 18. In addition, it obtained a mean value (average) $=22$, median $=23$, mode $=23$, standard deviation $=2.36$ and range $=8$. for more details variable frequency distribution groups forehand drive skills can be seen in the table below:

Table 2. Frequency Distribution Skills Forehand Drive

\begin{tabular}{ccl}
\hline Class Interval & Fa & Fr $(\%)$ \\
\hline $18-19$ & 3 & 20 \\
\hline $20-21$ & 3 & 20 \\
\hline $22-23$ & 7 & 46.67 \\
\hline $24-25$ & 0 & 0 \\
\hline $26-27$ & 2 & 13.33 \\
\hline amount & 15 & 100 \\
\hline
\end{tabular}

In Table 2 above of 15 samples, 3 (20\%) have the skills forehand drive ranges between $18-19,3(20 \%)$ have the skills forehand drive ranges between 20-21, 7 (46.67\%) skills forehand drive ranges between 22-23, $0(0 \%)$ skilled forehand drive ranges between 24-25, 2 (13.33\%) have the skills forehand drive ranged between 26-27.

From the above it can be argued from the 15 samples, that scored above average there were 2 people (13.33\%), which has a score in the average group were 7 of them $(46.67 \%)$, and the have a score below average there are six people $(40 \%)$

Based on the above concluded that the skills possessed forehand drive Semen Padang Table Tennis Athletes not in accordance with the desired expectation, with these can affect athletes in scholastic achievement. For more details can be seen in the frequency distribution histogram forehand drive skills below:



Figure 2. Distribution Histogram Skills Forehand Drive
Test Requirements Analysis

Table 3. Summary of Normality Test

\begin{tabular}{cccc}
\hline Variables & Lo & $\begin{array}{c}\text { Lt } \square= \\
0.05\end{array}$ & Conclusion \\
\hline $\begin{array}{c}\text { Arm } \\
\text { Muscle } \\
\text { Strength }\end{array}$ & $0.11 \epsilon$ & 0.22 & Normal \\
\hline
\end{tabular}

To determine whether the data were normally distributed variables studied or unusable Liliefors test.

3. Based on the above table, it turns out the test results in the observation Liliefors Lo $<\mathrm{Lt} \square=0.05$, if Lo is smaller than $\mathrm{Lt}$ this means that the data normally distributed variables studied.

\section{Hypothesis testing}

Arm Muscle Strength contribution by Skills Forehand Drive

The first hypothesis proposed in this study is whether there is a significant correlation between muscle strength Contributions arm (X1) with the skills of Table Tennis Athletes forehand drive cement field (Y). To determine this contribution is made simple correlation analysis. Summary results of the calculation can be seen in the following table:

Table 4. Summary of Product Moment Correlation (rxy)

\begin{tabular}{cccc}
\hline Variables & rxy & $\mathrm{t}_{\text {observe }}$ & $\mathrm{t}_{\text {table }}$ \\
\hline Arm Muscle & & & \\
$\begin{array}{c}\text { Strength (X) } \\
\text { Skills Forehand } \\
\text { drive (Y) }\end{array}$ & 0.64 & 3.01 & 2.16 \\
\hline
\end{tabular}

Results of the calculations in Table 4 above shows that the correlation coefficient between the arm muscle strength against skill forehand drive is positive, it is seen that from a statistical analysis acquired $r_{\text {observe }} 0.64$ and $r_{\text {table }}$ in early stages $\square=0.05$ by 0.553 thus $r_{\text {observe }} \square r_{\text {table. While }} t_{\text {observe }}$ 3.01 and $t_{\text {table }}$ in early stages $\square=0.05$ by 2.16 thus $t_{\text {observe }}>t$ table. This means there is a significant contribution between the arm muscle strength against skill Athletes table tennis forehand drive Semen Padang.

\section{DISCUSSION}

Arm Muscle Strength contribution to Skills Forehand drive. In some opinions presented by experts in [9] that gives a sense of strength:

"Friedrich (1969) argued, power is the ability of a muscle to work optimally withstand the load. Costill (1979) points out, the strength is the maximum ability to conduct or resist force. Verducci (1980) points out, the strength is the strength of muscle contraction in activity. Fox (1988), muscle strength is a muscle power or pressure, or rather is a group of muscles that can be used against a resistance in a business / maximum effort".

From the opinions expressed in the above it can be concluded that the arm muscle strength is the ability of the arm muscle or group of muscles to hold or receive a load at 
work. So power is one of the important components of physical condition in sporting activities. Strength is the driving force of any physical activity. Muscle strength better arm is capital in making a forehand drive with good skills in the sport of table tennis.

The research proves that there Contributions significantly between the arm muscle strength against forehand drive with acquired skills rhitung 0.64 and rtabel in early stages $\square=$ 0.05 at .553 with a contribution of $40.96 \%$. Thus, the strength of the arm muscles contribute to skills forehand drives of $40.96 \%$ while the remaining $59.04 \%$ is caused by other variables, such as: agility. grip strength, flexibility togok, hand eye coordination, perkenaan ball on the bet and the timing of the ball when hit.

\section{CONCLUSION}

Based on the research conclusions can be stated as follows: there is a contribution to the arm muscle strength skills of table tennis athletes forehand drive Semen Padang.

\section{REFERENCES}

[1] UU. "Tentang Sistem Keolahragaan Nasional”. 2005. pp. 34-56

[2] Damiri, Ahmad dkk. "Olahraga Pilihan Tenis Meja". Bandung: Depdikbud. 1991.pp.45-56.

[3] Hodges, Larry. "Tenis Meja Tingkat Pemula". Jakarta: Raja Grafindo Persada. 1996.pp.12-24

[4] Simpson, Peter. "Teknik Bermain Pingpong”. Bandung: Pionir jaya. 1986.pp.77-90

[5] Kertamanah, Alex. "Teknik dan Taktik Permainan Tenis Meja Dasar". Bandung: Raja Grafindo Persada. 2003.pp.34-47

[6] Irawadi, Hendri. “Kondisi Fisik”. Padang: FIK UNP. 2010.pp 7-20

[7] Suwirman. "Metodologi Penelitian". Padang: FIK UNP. 2011pp.34-42

[8]Sugiyono. "Metode Penelitian Pendidikan". Bandung: Alfabeta. 2007.pp.77-90

[9] Arsil. "Pembinaan Kondisi Fisik". Padang: FIK UNP. 2007.pp.44-55 